\title{
Vark Questionnaire Online Platform as a Spearhead the Effectiveness of Styles and Methods of Teaching Teachers
}

\author{
Athalla Nauval Bhayangkara \\ Department of Educational Management \\ Universitas Negeri Malang, Indonesia \\ athalla.nauval@yahoo.com
}

\author{
Dandy Bayu Firdaus \\ Department of Educational Management \\ Universitas Negeri Malang, Indonesia \\ danz2614@gmail.com
}

\author{
Tanti Minawati Pratiwi \\ Department of Educational Management \\ Universitas Negeri Malang, Indonesia \\ tantimp02@gmail.com
}

\begin{abstract}
This article was created to provide recommendation for a teacher as the key to transfer the knowledge, to determine the appropriate teaching style and learning method to apply to a class that is generally per class have different learning styles or typologies of learning. Vark Questionnaire Online is a tool commonly used to diagnose accurately related to an individual's learning style. The method used by the compilers in drafting the article is to use a literature review of the primary reference of research, as well as a secondary reference book that has high credibility. What it's found in this paper through the study of the various references are: (1) teacher teaching style affects the learning motivation of students; (2) Online Vark Questionaire is rated effective to determine the appropriate learning style for learners; and (3) learning styles and proper teaching methods can make classroom management accomplished effectively and efficiently. Based on these findings, the author finds a recommendation regarding a variety of teaching styles and teaching methods suitable for the majority of class-owned learning styles by applying the Vark Questionaire Online as the majority determinant of the class has a learning style. Based on the findings and results obtained in this article, it can be concluded that the Vark Questionaire Online can be used as a tool to determine the teaching style and learning method suitable for teachers.
\end{abstract}

Keywords: teachers, learning style, teaching style, vark questionnaire online

\section{INTRODUCTION}

Education can be interpreted as a conscious and planned endeavour through affective or attitude, teaching or cognitive mentoring, and skills or psychomotor related training to learners to go to or enter the future [1]. Departing from this statement can be concluded that education is self-taught, ranging from cognitive, affective, and psychomotor authority to have the competitiveness to be living in the future. Switching from this, in the modern era is now the era of the Industrial Revolution 4.0. The phenomenon that will emerge as a result of the Industrial Revolution of 4.0 is the economic aspect with a global scale will be integrated following the development of technology, as well as science intervention.

The second phenomenon, a country that has high progress in the field of technology and science that can take an opportunity from the Industrial Revolution of 4.0 will achieve an edge that stems in a state's prosperity. Lastly, if a country cannot advance its development in technology and science, there will be a stuck improvement in a country, which leads to no livelihood in the country, even Can be fatal, such as the crisis that will occur in the country both in the field of economics, politics, education, and so on.

The progress or success of a country is certainly supported by the high capability or high competence of human resources owned by the country. To create a high human resource, it is required an integration of the education process, therefore the role of education is judged to have high urgency in forming a quality human resources. The idea is aligned with [2] that education is a process of humanizing people to prepare himself in the future. It certainly refers to the importance of education, to direct human beings into individuals who are known to prepare as a provision in the future.

The success of a process of education in addition to being kept by the quality of facilities and infrastructure, quality governance of management in an educational institution, as well as stable finance to support the educational process, is also determined by Managing Teacher's classroom skills [3]. That is to say, teachers as individual educators who transfer knowledge to students must also be able to manage the class and also become leaders in the learning, which is considered a sense in the substance of education management, namely Management class. The purpose of class management for learning [4]: (1) makes learning as simple but still effective; (2) overcoming learning barriers; (3) arranging learning facilities; (4) nurture and guide learners according to the background of their individual nature; (5) help learners learn and work according to their abilities; (6) create a good social atmosphere in the classroom; (7) to set the learning. concerning this, it can be concluded that integrated class management can affect the achievement of students academic competence in real.

At a glance the achievement of education in Indonesia can be measured from Indonesia's ranking in PISA (Programme International for Student Assesment), Indonesian education was ranked 62 from 72 countries that handled PISA in the competency assessment in Mathematics, Science, Reading. If we want to attract the results of PISA (Programme International For Student Assesment) that is shown that Indonesia is ranked 72 from 80 countries, in which case there is a role or teacher. The teacher is the individual who has responsibilities related to educating and building a student in the scope of the school 
to become an independent human, capable, obedient to God and make the individual social creatures [5].

From these statements and ideas form a paradigm, the teacher is an individual who performs teaching and learning activities. Teaching himself, derived from the Old English, the word Taecan who later became teach [3]. If seen from the perspective of a word, rationally teach or teach means to show or explain something to someone in various ways to raise or grow a response about an incident, a science, and another.

Descriptively teaching is interpreted as the process of conveying information or knowledge and motivation from Guru to learners [6]. Therefore, the process of delivering information from Guru to the learners is often regarded as transferring knowledge. To maximize the teaching essence of the teacher, it is necessary to tailor the teacher's teaching suitability tailored to the relevant student characteristics, according to the purpose of the management of the class itself, which has been written at the previous level.

Students in learning generally have different characteristics: (1) visual, a student will understand when looking at the material explanation through image projection or exposure in the form of Physical learning; (2) Aural, a learner is able to understand a learning material when explained orally; (3) Read/write, i.e. a student will master a material when reading or writing a material that has been displayed by the teacher; (4) kinesthetic, a disciple will understand a material when they are in motion, such as reading while moving the hand, reading while walking, demonstrating an understanding through gestures. Vark Questionnaire Online is an online website that has a high credibility related to the results of its sensitivity to an answer that has been filled correspondents, in addition to the online Questionnaire Vark many become a referral to Determine the appropriate learning methodology for an individual when learning to be seen from its popularity in various countries [7]. Vark Questionnaire online in determining which learning method is suitable for an individual is to provide a simple question-shaped questionnaire with multiple choice answers, which is then filled by respondents according to their interests. Then, when the correspondent finishes filling out the double-choice questionnaire, there will be a clear explanation of the appropriate learning methods used for each individual associated.

If examined more deeply into the rational number of compilers that have been displayed, the red threads can be drawn with the ability to identify effective methods of learning for an individual, of course, it is In determining an effective class management approach to a learning group. Based on the background, and the study of the various theories, data, and rational exposure that has been presented by the drafting team, the research issue of this literature review is: how to utilize online Quiestionaire Vark as The cutting edge of an effective class management approach?

\section{METHODS}

At the glance of this article, it is compiled by using a critically and comprehensively review of the literature. With regards to various sources studied and reviewed by the compilers, using two referral sources, the primary reference source of early scientific work and published scientific articles with highly credibility-weighted index and a secondary reference source in the form of a textbook. The team chose to use this method due to making recommendations regarding the context of the research compiled by the authors, just using the study of the library can be found a credible research result. Various exposure above following [8], the literature study can be used as a tool to construct a framework for completion when facing a problem. In connection with the literature study method itself can also be used as a cornerstone of discovering new theories when the study of a primary reference in the form of scientific work is critically studied [9]. A variety of new results and findings, as well as recommendations successfully discovered by the drafting team using the literature review method.

\section{RESULT}

The execution of a study in the scope of formal education will not be separated from the role of a teacher as teacher, mentor, coach, and trainer for students [1]. To apply various functions or roles of the teacher especially related to its function as a teacher, it takes a method, so that the cognitive realm, as well as the essence of, transfer of knowledge, can be achieved optimally. In line with the idea [10] confirms the various learning methods that can be used by teachers to optimize the achievement of learning objectives in the class: (1) outdoor method, meaning on the method of learning Thus it is teaching by conducting an activity outside of class, in this method of learning as a teacher plans, executes, and evaluates this learning system so that when this learning progresses, The activity is not out of the intention and purpose of learning itself; (2) talking Stick method, the basic assumption is the provision of the material in the form of handout or material delivery based on the textbook, this study marked by the teacher who gave instructions to read the material, then after the reading was finished, the teacher gave a stick or stick to one of the students, then the student should explain the material that has been read; (3) the simulation method, which is a method that refers to the action of all learners to cross out an existing learning, such as playing English language play, or playing a regional drama story to solidify linguistic intelligence of students [11], explains that simulation is a learning method by simulating various roles related to learning; (4) discovery learning methods, essentially diasamsuikan as learning by looking for the learning materials and find the solution of the problem by the students themselves [4], meaning that the teacher here only serves as Facilitator when a student is caught discovering a complex problem, as well as providing a simulation that contains the issue or exposure to a description of the problem spoken by a teacher; (5) a method of brainstorming, is a method by adapting a group discussion between a student and a teacher, or a student in a class with a related teacher, it is enabled so that the student can think critically with the problem or a material learning, brainstorming is also effective for collecting ideas and opinions [12]; (6) A method of discussion, essentially a systematic, directional, and explicit purpose-directed conversation, which means that a scientific conversation by a class member is either an individual with an individual, as well as a group with a group to be An existing problem solving. 
The different methods of learning are also correlated with the teaching style applied by the teacher, when the teacher's teaching style corresponds to the climate and the background of the pupils related to his or her learning interests or style when understanding A new science, it will be formed a synergy that comes down to achieving the optimal cognitive realm. The notion is linear with the statement [13] that, teaching styles and learning methods that suit the willingness of the majority of students in the classroom, will increase its efficacy for study, due to extrinsic motivation as well as motivation Intrinsic in the students will evolve with harmony. In terms of what has just been shown, here are the various teaching styles available for teaching [14]: (1) the classical teaching style, is a teaching that adheres to teacher-centred which means learning centres are teachers, therefore a teacher is obliged to fully master the lessons taught by him; (2) the technological teaching style, is dependent on props and learning media, to support the implementation of an achievement of learning objectives; (3) a personalized teaching style, the basic assumption of this teaching style is that teachers with an inter the approach will maximize each student's interest thoroughly, so that students can thrive with their interests and talents; and (4) an interfraction teaching style, is a teaching style that puts forward a change of behaviour and arises a dynamic interaction between all members of the class, a teacher with students, and students with students to maximize the cognitive realm, psyteric, and psychomotor students.

Switching from this, each student or individual has different ways to learn or understand something, which is called the learning style. In tune with the exposure [15], it explains the idea of understanding everything an individual has in its learning style to internalize it in their cognitive sphere, from the notion that the author Also argues that learning is the process of an individual who does not know, to know [16]. The main learning styles that are generally owned by each individual: (1) visual learning styles; (2) kinaesthetic learning style, and; (3) audio learning style. Visual learning style is a learning style by advancing the senses to capture an event, science, or new knowledge that is then understood by the individual to be new information in the brain that can be kept in mind.

Then, kinaesthetic learning style is a learning activity in which individuals can understand everything with the practice directly to the field, or using a link and match learning in open practice outside of class, and can understand something By acting, fingered, always oriented with a physical motion to understand new information. While the auditory style of auditorial is, a learning style with hearing-promoting to intervening new information into an individual's mind or understanding. The various exposure is: visual learning style is a learning style by viewing or reviewing directly related to the learning object, while the audio is by hearing an individual can understand something new, and kinaesthetic is the orientation of an individual's body movement will be aware of new things [17].

At a glance about the development of research or knowledge about the learning style, the more days are also increasingly complex related descriptions in each learning style. In accordance with the statement [18] gives a review and explains a more complex learning style that is a style of learning VARK (Visual Audio Read/Writing Kintesthetics), is a learning style by classifying an individual to 4 categories, namely: (1) visual; (2) audio; (3) read/writing; and (4) kinesthetics. The etymological and terminological aspects of VARK is the same as other learning styles, only adding a new style that was previously not disclosed, namely read/writing. Read/writing, is an understanding of information that can be internalized into the realm of human memory when an individual reads or writes new information or science. VARK itself has an official website that has been verified to be the defining platform of learning style owned by an individual, through the Vark Questionaire Online an individual will be given a questionnaire that refers to What learning style is best to implement to the respondent. This can also be obtained for free by the respondent if only want to know the appropriate learning style for himself.

Latest research or research related to the effectiveness of Vark Questionaire Online as a defining learning style of a student is quite efficient to determine the learning style of an individual or a student. The results of the research showed a result through statistical trials which were later disengaged in a research conclusion, that a student is more interested in what is learned when the study style used by the individual According to the type or style of learning on him. Later, thanks to Vark Questionnaire Online A student in the research can develop his ability to understand something optimally. Moving on from the previous thing, [19] assumed, that Vark Questionnaire Online could be a cornerstone for educators to develop styles, strategies, and learning models for their students, so that information delivery can be achieved optimally.

Various other research, the results are also linear with findings from the authors about the effectiveness of online Vark Questionaire on learning development, as well as determining teaching strategies. As research [20] shows that Vark Questionnaire Online can be used as a platform to determine the appropriate learning style implemented in the class specifically and accurately. Therefore, the red thread can be pulled, that the presence of the Vark Questionaire Online as a platform of determining learning style must be utilized directly by the teacher to boost the transfer of knowledge from teachers to students in particular. Then, it can also be concluded that a learning style becomes an important determinant in achieving success in the sphere of education.

Teaching and learning teachers in Indonesia can also be said to be less attractive, and less motivating learners. It can be expressed in such a way as seen from the achievement of Indonesian education competence in PISA (Programme International For Student Assesment) is located at the rank of 62 from 72 countries. From this, it can be drawn red thread, that teachers as educators can not be a SCIENCE communicator in learning. Not as difficult as teaching with the students' learning typology, the lack of variation in learning, the low value of the UKG (Master Competency test), also a factor in the cause of lack of understanding of pupils or students in understanding the subjects presented by Educators.

The rational and related data hormonal of the teacher's learning is also supported by recent research [13], which shows that lack of variation in teaching style, as well as delivering material that does not motivate learners 
Students may be less able to focus their attention on teachers who have the subject. Another finding in the study, was data analysis using descriptive analysis in the form of a percentage, as well as correlation analysis with Chi-Square, indicating that $70 \%$ of students assumed that teacher teaching methods and styles did not match the students. Based on a variety of exposure by compilers, it is a conclusion that teachers need to use a proper learning strategy and teaching method, so that students will always want more to learn, as well as for the optimization of transfers of knowledge that is more optimal and quality.

In this context, the author will expose rational thinking, the Vark Questionaire Online as the foundation of a teacher to determine the teaching style, teaching method, or learning model that will be applied and implemented to students [19]. A learning style and the proper teaching method of the teacher will give a higher passion and make learners feel enjoy when learning. From the opinion, it will certainly come down to the essence of the transfer of knowledge that is optimal and quality.

Related to the implementation of Vark Questionaire Online to students in school, it can be done easily by simply accessing the Vark Questionaire Online website on Google, then by instructing students to fill the various questioners According to the will and appropriateness of his thinking. When a student finishes completing the existing questionnaire, a classification of the respondent or student is classified as the study style as defined by the VARK itself. Various classifications are visually large, auditory, read/write, kinesthetics. All of these classifications are based on the results of the questionnaire that has been created by Vark Questionaire Online.

\section{DISCUSSION}

What it's found in this paper are the implications of which models and teaching styles are suitable to be implemented in a class scope, referring to the majority of the learning styles that a group of students have in the scope of the class where the results of the majority Various learning styles are acquired through Vark Questionaire Online. In this discussion, based on the results of highcredibility research, as well as the support from the various library studies that the drafting team has gathered, the drafting team will display some recommendations regarding the appropriate learning model in Classes to make classes more effective in learning in classrooms.

In the case of the majority of the class learning style or the learning type of a student is the type or style of audio learning, the suitable learning model applied to the student is with an interfraction teaching style, as explained that The interfraction teaching style is centred on providing a learning information with the teacher as a learning centre by explaining the material explicitly in front of the class by including dynamic Communication [3].

Departing from the idea, it can be examined that the inter transactional teaching style is learning teachercentred but learners still have a share of learning, meaning teachers as educators explain a Learning by having a direct face with the main student with the explanation directly through communication derived from the pronunciation. Thus, the composer assumes that a study with an interfraction style is effective for classes with the majority of students who are auditorial-learning styles. Then, to support complex teaching, related to the majority of students with the type or style of auditory learning is to imply a model of discussion learning and brainstorming in learning, because two models The study emphasizes the auditory realm when applied in practice.

The opinion is supported by the opinion [10] that a brainstorming study was learning by emphasizing lectures on pupils combined with the giving of questions during a lecture. While the discussion, is the provision of learning materials with two-way communication, both students with students, and students with teachers. Prior exposure to the implementation of the Inter fractional teaching style and brainstorming learning model, as well as discussion, certainly comes down to the effectiveness of learning in a class sphere that the majority of the auditorial learning style.

Then, if in a class the majority of students have a visual learning style a suitable teaching style is to apply the classical teaching style and technological teaching style, which is accompanied by a variety of learning models. The classical teaching style is judged to fit by the authors implicit in the class that majority have a visual learning style due to the classical teaching style referring to the material giving by the teacher in various ways, such as through class lectures, Exposure to images or the use of props described by the teacher, as well as the technological teaching style that refers to the use of the learning media as a refinement of the classical teaching style. Compilers can argue in such a way, for capturing information if a student has a visual learning style will be easier when the teacher explains with the methods of lectures and the learning media [21].

From the rationale, the composer can give a recommendation, that the classical teaching style for the majority of classes with a visual learning style would be suitable when combined with a talking stick learning model and an outdoor learning model. Because in the outline of the Talking Stick learning model is the gift of a stick to the students of the teacher randomly, whoever receives the stick then the student explained about the related material. While outdoor learning is more emphasis on the immediate review of the reality in the field, by matching on the existing material, it forms a link and match in the learning. The team also argues that giving material through video will also add to the effectiveness of learning, as visual learning styles will understand the material when it captures with its vision carefully [21].

When a majority class condition has a learning style that is inclined to read/writing, a suitable teaching style is implied to the students is a classical teaching style, as well as internalizing the Talking Stick learning model as Variation of learning. In line with the idea [14] explains that a classical teaching style will stimulate a learner to focus on the teacher when giving a lesson in class. Connecting from these ideas, talking stick learning is also judged to be effective and efficient learning for the majority of classes with reading/writing styles. Because the basic assumption of a talking stick model is the structuring of the teacher to read a textbook or learning book, it can certainly address the majority of learners in a classroom sphere to understand learning and according to the learning style of the related class. The author, also argues that giving the handout of the teacher in each subject will 
accommodate the needs of the student regarding the fulfilment of the information of existing learning.

In relation to existing learning, if in a class the majority of students have kinaesthetic learning style, then the teaching style is suitable to be implemented to the classroom environment in such a way is to apply the teaching style Personalization, and application of outdoor and simulated models or methods, in order to achieve learning objectives in the form of internalization of subject information to the cognitive realm of learners that are effective and efficient. Because outdoor learning and simulation learning is learning with actions that involve a physical exercise or psychomotor sphere to review or discuss a subject.

The notion is linear with opinion [22] it takes a physical motion as well as motor activity to internalize the information in the students with Kinaesthetic learning style. Based on the exposure the red thread can be drawn that the personalised teaching style is assessed as effective for this context, as the personalized teaching style puts forward more attention to each student, when in this context, the personalized teaching style makes a learner feel aware, guided, and trained intensively so that it comes down to achieving optimal cognitive, affective, and psychomotor, despite the learning style a student is a kinaesthetic learning style.

Switching from a variety of topics that have been presented by the drafting team related to teaching style and suitable learning methods implemented for each student learning style, the composer argues that teacher teaching orientation should pay attention to A variety of students ' learning styles, but it is necessary to imply a style or method of learning that is varied, so that motivation and learning tips always appear, and not the creation of boredom. [13] That variations in learning are useful and implicates on achieving a productive climate in the classroom.

\section{CONCLUSION}

Vark Questionaire Online, as a learning style platform for students, is assessed as effective to be applied in a sphere of learning in the classroom, because based on the past scientific works of various scientific works refers to the effectiveness of Use of the platform. Then, based on a variety of literature and study of primary reference source in the form of scientific work, which is then generalized by the author into a new findings and recommendation, it can be concluded, that the teaching style and method Teaching by the teacher has full implications for the learning motivation that students have. The tendency of a student's learning style is closely related to the teacher teaching style and teacher learning methods to achieve effective and efficient learning objectives.

Vark Questionaire Online is the right tool to achieve the optimization of the learning of an existing class. Because classification and psychological diagnosis by the platform is assessed accurately and precisely the target. Therefore, teachers or educators should use the Vark Questionaire Online as a tool to manage classes, as well as tools to achieve existing learning objectives. Then, it also takes an advanced study based on this article, to acquire a more comprehensive field of results and facts.

\section{REFERENCES}

[1] Triwiyanto, T. 2017. Pengantar Pendidikan. Jakarta: Bumi Aksara.

[2] Gunawan, I., \& Benty, D. D. N. 2017. Manajemen Pendidikan Suatu Pengantar Praktik. Bandung: Alfabeta.

[3] Wiyani, N. A. 2017. Manajemen Kelas: Teori dan Aplikasi untuk Menciptakan Kelas yang Kondusif. Jogjakarta: ARRUZZ MEDIA.

[4] Djamarah, S. B., \& Zain, A. 2010. Guru dan Anak Didik dalam Interaksi Edukatif Suatu Pendekatan Teoritis Psikologis. Jakarta: Rineka Cipta.

[5] Uzer, U. M. 2010. Menjadi Guru Profesional. Bandung: Remaja Rosdakarya.

[6] Evertson, Carolyn M, \& E. T. 2011. Manajemen Kelas untuk Guru Sekolah Dasar. Jakarta: Kencana.

[7] Peyman, H., Sadeghifar, J., Khajavikhan, J., Yasemi, M., Rasool, M., Yaghoubi, M. Y., Karim, H. 2014. Using VARK Approach for Assessing Preferred Learning Styles of First Year Medical Sciences Students: A Survey from Iran. Journal of Clinical and Diagnostic Research, 8(8), 14. https://Doi.Org/10.7860/JCDR/2014/8089.4667.

[8] Triyono. 2003. Beberapa Kelemahan Umum Proposal Penelitian Dosen Universitas Palangkaraya. Jurnal Pendidikan dan Kebudayaan, 42(9), 383-393.

[9] Howard, K., \& Sharp, J., A. 1993. The Management of a Student Research Project. Gower: Great Britain.

[10] Afandi, M., Chamalah, E., \& Puspita Wardani, O. 2013. Model \& Metode Pembelajaran di Sekolah. Unissula Press.

[11] Hamalik O. 2009. Proses Belajar Mengajar. Jakarta: Bumi Aksara.

[12] Hasibuan, J. 2008. Proses Belajar Mengajar. Bandung: Remaja Rosdakarya.

[13] Rahmat \& Jannatin. 2018. Hubungan Gaya Mengajar Guru dengan Motivasi. Jurnal Jurusan PGMI, 10(2), 98-111.

[14] Mulyasa, E. 2011. Menjadi Guru Profesional Menciptakan Pembelajaran Kreatif dan Menyenangkan. Bandung: Remaja Rosdakarya.

[15] Hurlock, E.B. 2000. Psikologi Perkembangan. Jakarta: Erlangga.

[16] Papilaya, J. O., \& Huliselan, N. 2016. Identifikasi Gaya Belajar Mahasiswa. Jurnal Psikologi Undip, 15(1), 56. https://doi.org/10.14710/jpu.15.1.56-63.

[17] Poter, D., \& H. 1999. Quantum Learning. Yogyakarta: Kaifa.

[18] Idrizi, E., Filiposka, S., \& Trajkovik, V. 2018. VARK Learning Styles and Online Education: Case Study. New York: Pearson.

[19] Wright, S., \& Stokes, A. 2015. The Application of VARK Learning Styles in Introductory Level Economics Units. Issues in Educational Research, 25(1), 62-79.

[20] Alina, Z. 2006. Learning Styles and Online Education. Campus-Wide Information Systems, 23(5), 325-335. https://doi.org/10.1108/10650740610714080.

[21] Bobek, E., \& Tversky, B. 2016. Creating Visual Explanations Improves Learning. Cognitive Research: Principles and Implications, 1(1), 1-14.

[22] Arylien Ludji Bire, \& Uda Geradus, J. B. 2014. Pengaruh Gaya Belajar Visual, Auditorial, dan Kinestetik terhadap Prestasi Belajar Siswa. Jurnal Kependidikan, 44(2), 168174. 